\title{
More Ulam for Your Brain: A Review on the Potential Role of Ulam in Protecting Against Cognitive Decline
}

(Lebihkan Ulam untuk Otak Anda: Suatu Kajian tentang Potensi Ulam dalam Lindungi Penyusutan Fungsi Kognitif)

\author{
YeEXING You, SUZANA SHAHAR*, HaSnAH HARON \& HANIS MASTURA YAHYA
}

\begin{abstract}
Ulam is the South East Asian traditional vegetables which contains high total phenolic content and exhibits antioxidant activity. Several studies have reported the potential of neuroprotective effect of ulam. The objective of this review article was to highlight the total phenolic content (TPC) and antioxidant activity of ulam and the roles of phenolic content that can contribute to attenuation of cognitive decline. The review includes randomized controlled trial and experimental studies from year 2007 to 2017. In this review, PRISMA method was used to report the results $(\mathrm{n}=15)$. Phenolic compounds, ie plants' second metabolites of selected ulam in South East Asia were also discussed in this review, with respect to its potential for health promotion which and reducing the risk of cognitive disease. Oenanthe javanica (selom), Ocimum basilicum (daun selasih) and Anacardium occidentale L. (pucuk gajus) were ranked in the top three highest TPC among all the selected ulam. In general, Polygonum minus (kesum), Anacardium occidentale L. (pucuk gajus) and Cosmos caudatus (ulam raja) exhibited high DPPH radical scavenging activity whereas Anacardium occidentale $L$. (pucuk gajus) exhibited highest ferric ion reducing potential (FRAP) among all the selected ulam in South East Asia countries. Overall, some studies had shown Centella asiatica (pegaga), Oenanthe javanica (selom), Polygonum minus (kesum), Ocimum basilicum (daun selasih) and Murraya koenigii (daun kari) are beneficial in improving cognitive status and mood. The bioactive compounds in ulam may exhibit neuroprotective effects but human studies are still lacking in exploring the relationship between ulam consumption and cognitive status.
\end{abstract}

Keywords: Antioxidant; cognitive; mood; phenolic; ulam

\section{ABSTRAK}

Ulam merupakan sayuran tradisi Asia Tenggara yang mengandungi kandungan fenolik yang tinggi dan menunjukkan aktiviti antioksidan. Beberapa kajian melaporkan ulam berpotensi sebagai pelindung neuro. Objektif kertas ini adalah untuk membandingkan jumlah kandungan fenolik (TPC), aktiviti antioksidan ulam serta peranan kandungan fenolik yang mengelakkan penyusutan fungsi kognitif. Ulasan kertas ini meliputi ujian klinikal dan uji kaji dari tahun 2007 hingga 2017. Dalam ulasan ini, kaedah PRISMA digunakan untuk melaporkan keputusan $(\mathrm{n}=15)$. Sebatian fenolik, i.e. metabolit sekunder tumbuhan daripada beberapa ulam terpilih di Asia Tenggara juga dibincangkan dalam ulasan ini daripada segi potensinya dalam mempromosikan kesihatan dan mengelakkan penyusutan fungsi kognitif. Oenanthe javanica (selom), Ocimum basilicum (daun selasih) dan Anacardium occidentale L. (pucuk gajus) merupakan tiga TPC yang tertinggi dalam kalangan semua ulam terpilih. Secara umum, Polygonum minus (kesum), Anacardium occidentale $L$. (pucuk gajus) dan Cosmos caudatus (ulam raja) menunjukkan aktiviti pemotongan radikal DPPH yang tinggi manakala Anacardium occidentale L. (pucuk gajus) menunjukkan potensi penurunan ion ferik tertinggi dalam kalangan semua ulam yang terpilih di negara-negara Asia Tenggara. Secara keseluruhan, beberapa kajian telah menunjukkan Centella asiatica (pegaga), Oenanthe javanica (selom), Polygonum minus (kesum), Ocimum basilicum (daun selasih) dan Murraya koenigii (daun kari) bermanfaat dalam meningkatkan fungsi kognitif dan emosi. Sebatian bioaktif dalam ulam berpotensi memberi kesan sebagai pelindung neuro namun kajian manusia yang menerokai hubungan antara pengambilan ulam dengan status kognitif masih terhad.

Kata kunci: Antioksidan; emosi; fenolik; kognitif; ulam

\section{INTRODUCTION}

Ulam is the traditional vegetables which are normally consumed in a raw form among South East Asian populations such as in Indonesia, Thailand and Malaysia. It is usually eaten together with rice-based meal or a blend of fermented sauces, such as budu, cincalok or sambal
(Huda-Faujan et al. 2007; Reihani \& Azhar 2012). Within Asian countries, more than 120 species of ulam have been discovered and they are rich in carbohydrates, proteins, minerals and vitamins (Mohd Shukri et al. 2011). Ulam or traditional vegetables which commonly consumed by the South East Asian populations are listed in Table 1. 
TABLE 1. List of selected ulam in South East Asia

\begin{tabular}{ll}
\hline Scientific name & Local name \\
\hline Anacardium occidentale L. & Pucuk gajus/ Yot-mamuang-himmaphan \\
Centella asiatica & Pegaga/ Gotu Kola/Antanan \\
Cosmos caudatus & Ulam raja/kenikir \\
Kaempferia galanga L. & Cekur \\
Mentha arvensis L. & Daun pudina \\
Morinda elliptica & Mengkudu \\
Murraya koenigii & Daun kari \\
Ocimum basilicum & Daun selasih \\
Ocimum americanum & Kemangi \\
Oenanthe javanica & Selom/Pak-Chilom \\
Parkia speciosa & Petai \\
Plucea indica $(\mathrm{L})$. & Beluntas \\
Polygonum minus & Kesum \\
\hline
\end{tabular}

On average, Malaysian adults consumed $40 \mathrm{~g} /$ person/day of ulam (Nurul Izzah et al. 2012). Many studies among animal and human have reported that ulam exhibit various medicinal properties, such as antidiabetic, antihypertensive, neuroprotective and anti-inflammatory (Amalia et al.2012; Bachok et al. 2014). The consumption of ulam has been promoted in key message 5 in the Malaysian Dietary Guidelines 2010 (National Coordinating Committee on Food and Nutrition. Ministry of Health Malaysia 2010) as ulam tends to increase the serum of Vitamin C, E, folic acid, $\beta$-carotene and lycopene. It has also been reported to be rich in polyphenols ( $\mathrm{Su} \& \mathrm{Arab} 2006$ ) that may be beneficial in improving cognitive status (Rosli et al.2014). Medicinal plants such as herbs and ulam are therapeutic agents which have been used in many cultures but studies regarding the development of ulam as fortified food products are still limited.

Mild-cognitive impairment (MCI) is the intermediate stage between healthy aging and dementia (Petersen et al. 2014). Individuals with MCI have been identified to be at a higher risk of developing dementia after a few years (Burns \& Zaudig 2002). A study has estimated that dementia and Alzheimer's disease in the world will be doubled for every 20 years and reach 81 million by 2040 (Reitz et al.2011)and is predicted to double every 20 years through to 2040, leading to a costly burden of disease. Alzheimer disease (AD. Specifically in South East Asia there were approximately 2.48 million dementia patients in 2010 and the number is estimated to increase to 11.13 million in 2050 (Prince et al. 2013). According to the National Health Morbidity Survey, the prevalence of poor mental health among Malaysian aged above 16 years old ranged from $19.6 \%$ to $34.7 \%$ (Institute for Public Health 2015). The prevalence of mild cognitive impairment in Malaysia's elderly population was $16 \%$ (Vanoh et al. 2017). Previous studies have reported the favorable effect such as Polygonum minus supplementation has improved both attention and memory among middle aged women (Shahar et al. 2015). Furthermore, Ginkgo biloba and Centella asiatica have improved cognitive impairment related with aging and other disorders such as Alzheimer and dementia (Gambhir 2008; Solomon et al. 2002). However, such benefits of ulam are yet to be reviewed systematically for its neuroprotective effect among South East Asian populations.

\section{METHODS}

The search for published research papers that related to ulam consumption and cognitive status were conducted on PUBMED, Science Direct, Scopus, Springer and Google Scholar databases for articles published from 2007 to 2017 by using PRISMA method (Fokkens et al. 2005). The review includes randomized controlled trial and experimental studies. The keywords that were used in the database machine comprises of ulam consumption, total phenolic content, antioxidant activity and cognitive function among animal, adult and elderly population. A total of 138 records were identified through database searching, 123 records were excluded due to irrelevant content, ulam was not found in South East Asia countries and duplicate studies. Thus, a total of 15 studies were included in this review article (Figure 1). Local journals and unpublished theses were hand searched. Since the study is a review article, ethics approval is not required.

\section{RESULT}

\section{PHENOLIC CONTENT AND ANTIOXIDANT ACTIVITY OF SELECTED ULAM}

Total phenolic content of selected ulam Out of seven studies concerning total phenolic content and antioxidant activity of selected ulam in South East Asia, five studies were conducted in Malaysia and one study each conducted in Thailand and Indonesia, respectively (Table 2). Phenolic compounds are plants' secondary metabolite which have the potential in promoting health and possessed medical benefits (Mohd Akhtar et al. 2011). Phenolic compounds contribute as an antioxidant by scavenging the superoxide anion, hydroxy radical, peroxy radical and inhibiting lipid peroxidation in the biological system (Izunya et al. 


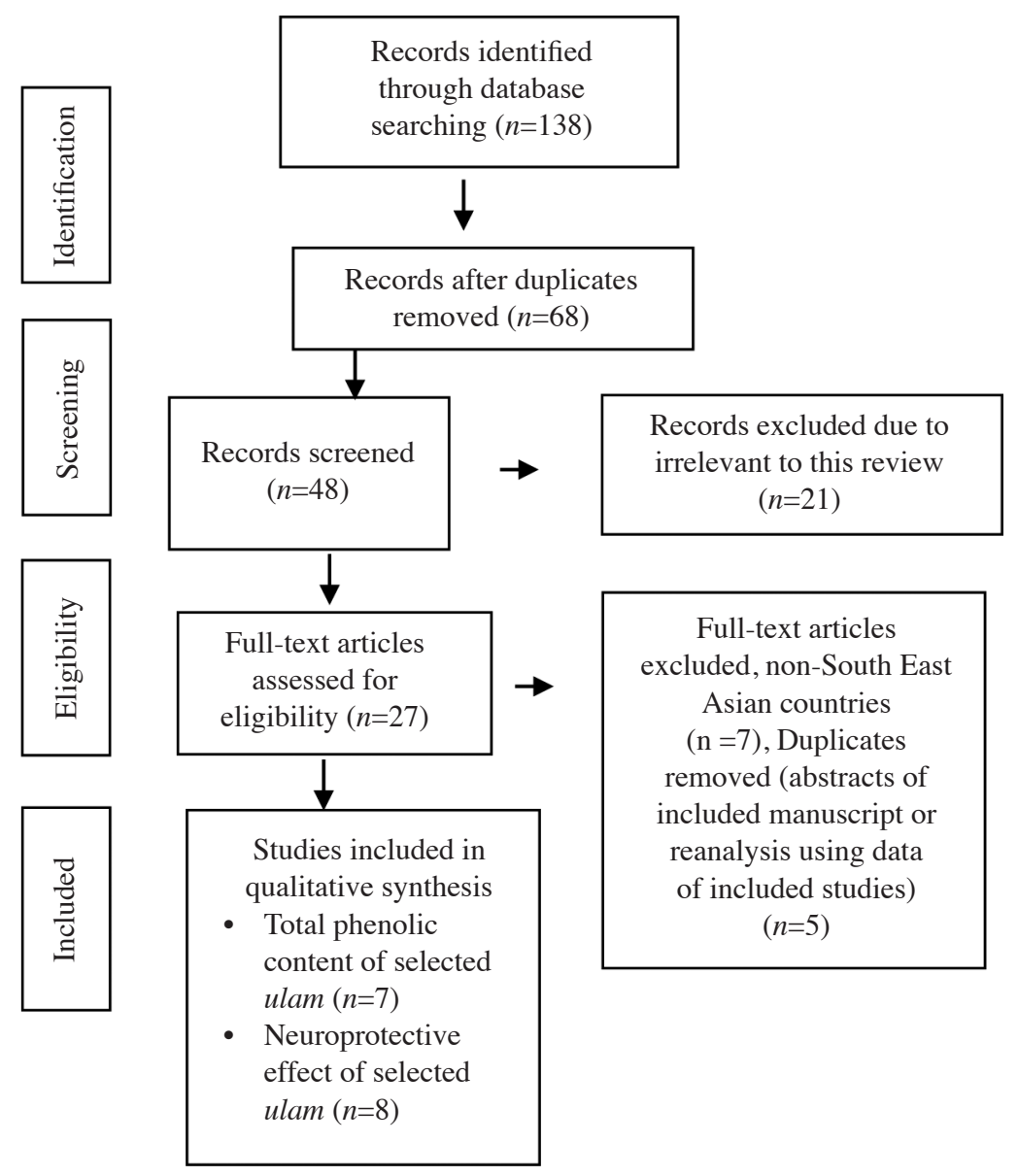

FIGURE 1. Review article flowchart

2010). Nowadays, consumers are concerned about the safety of the synthetic antioxidants products in market and looking for the natural products. Thus, many studies have been carried out to identify the safe and edible plants as supplements to overcome the health issues (Maizura et al. 2011). All the studies reviewed have used Folin-Ciocalteau method to analyze the TPC. The study by Nooraini et al. (2015) has determined TPC of kesum, pegaga and ulam raja extracts. For the pure extracts, the highest TPC was kesum $(1388.19 \pm 111 \mathrm{mgGAE} / 100 \mathrm{~g})$, followed by ulam raja $(323.59 \pm 7.19 \mathrm{mgGAE} / 100 \mathrm{~g})$ and pegaga $(150.01$ $\pm 37.93 \mathrm{mgGAE} / 100 \mathrm{~g})$.

Another study in Malaysia by Reihani and Azhar (2012) has summarized the TPC of selected ulams in the following order: daun kari, selom, ulam raja, pegaga and petai. The extraction method used was $0.5 \mathrm{~g}$ of powdered sample added with $25 \mathrm{~mL}$ of deionized water. In another study, $1 \mathrm{~g}$ of powdered sample extracted with $50 \mathrm{~mL}$ methanol was used to analyze the TPC of selected ulam and ranked in the following order: pucuk gajus, kesum, ulam raja, selom and pegaga (Chiang Chan et al. 2014). Another study has used four different extraction methods to analyze the TPC of ulam, namely extraction in $70 \%$ acetone, $70 \%$ ethanol, $70 \%$ methanol and distilled water (Sulaiman et al. 2011). A study in Thailand reported the TPC of Anacardium occidentale L. as $4075.79 \pm 54.24 \mathrm{mg}$
GAE/100 g (Kongkachuichai et al. 2015). In Indonesia, the TPC of selected ulams can be ranked in the following order: Cosmos caudatus, Centella asiatica and Plucea indica L. (Andarwulan et al.2010). Apparently, there was a variation in TPC of selected ulam among these different extraction methods. In general, selom, daun selasih and pucuk gajus were top 3 highest TPC despite the different methods of extraction.

DPPH free radical scavenging activity of selected ulam DPPH (1,1-diphenyl-2-picrylhydrazyl) radical-scavenging activity was performed to analyze the antioxidant activity of selected ulams in South East Asia (Brand-Williams et al. 1995; Mavundza et al. 2010). The assay was based on the reduction of DPPH radicals which causes an absorbance drop at $515 \mathrm{~nm}$ of spectrophotometer. All samples were analyzed in triplicates and average of the results was reported. The antioxidant capacity was expressed as $\mu \mathrm{mol}$ Trolox equivalent or $\mathrm{mg}$ Gallic acid equivalent (Wong et al. 2006).

Reihani and Azhar (2012) study reported that ulam raja showed the highest antioxidant capacity followed by selom, daun kari, petai and pegaga. Daun kari has been identified to have the highest TPC but it has a relatively low antioxidant activity, probably due to poor specificity of the total phenolic assay (Escarpa \& González 2001; Singleton 


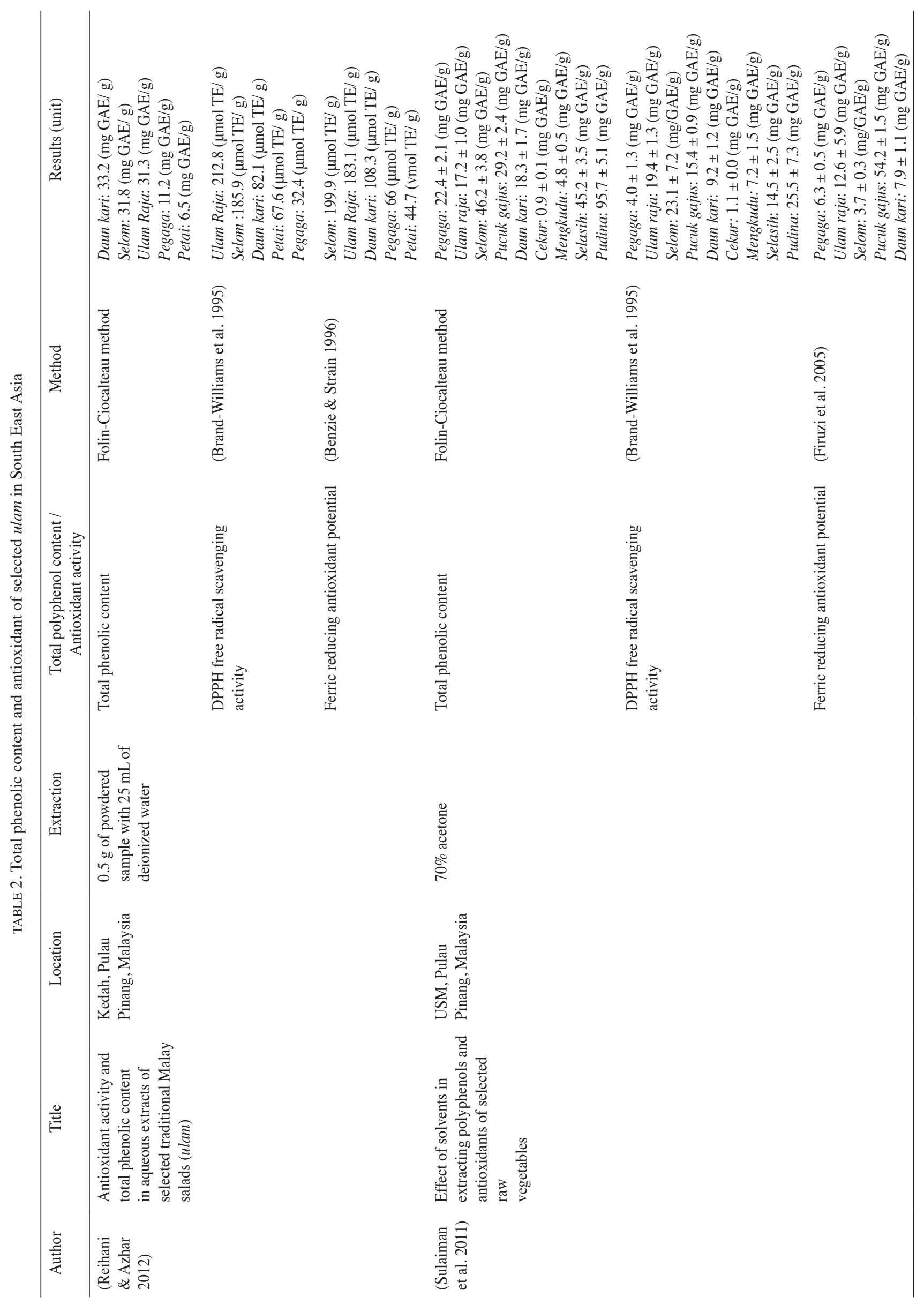




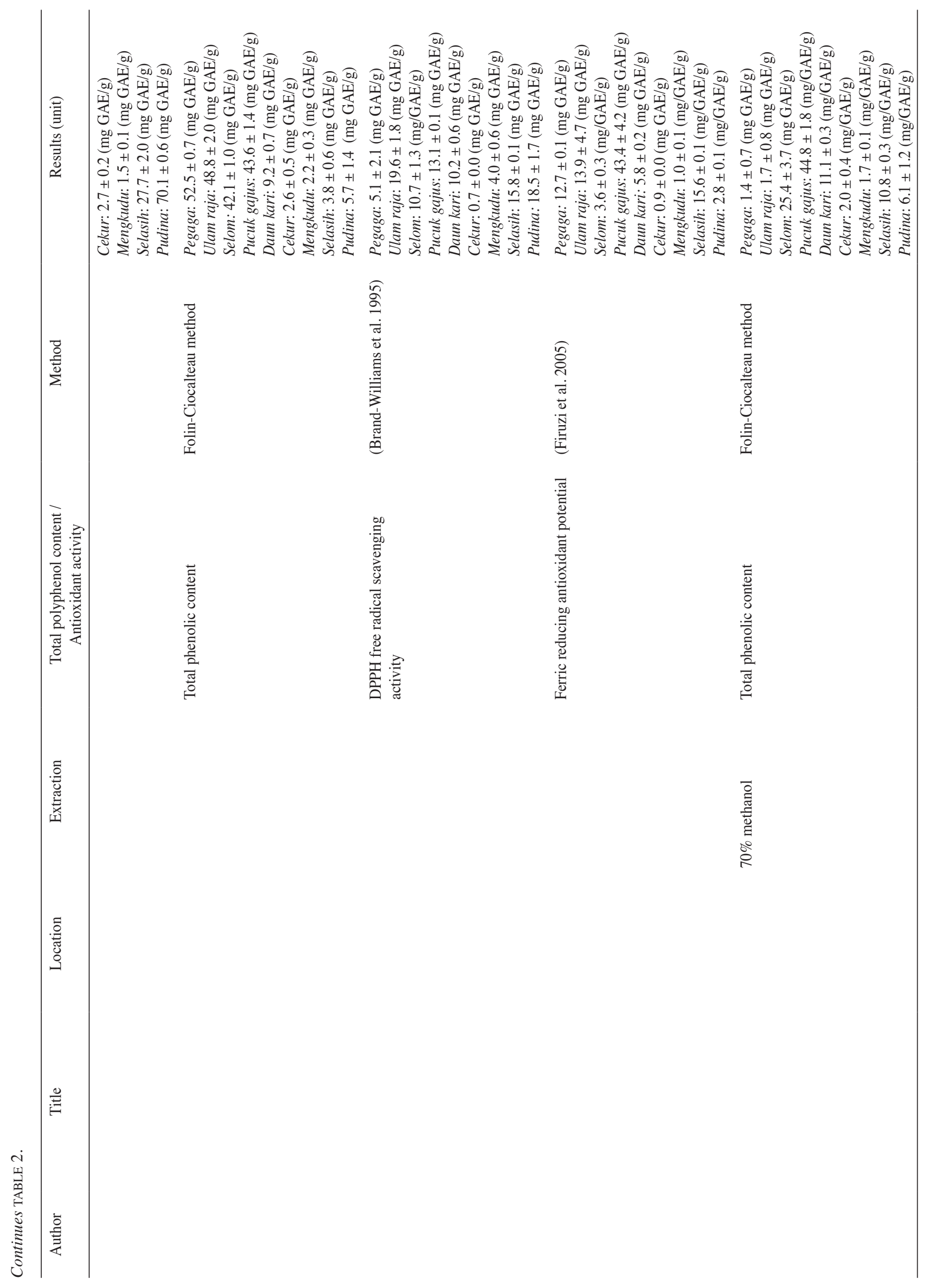




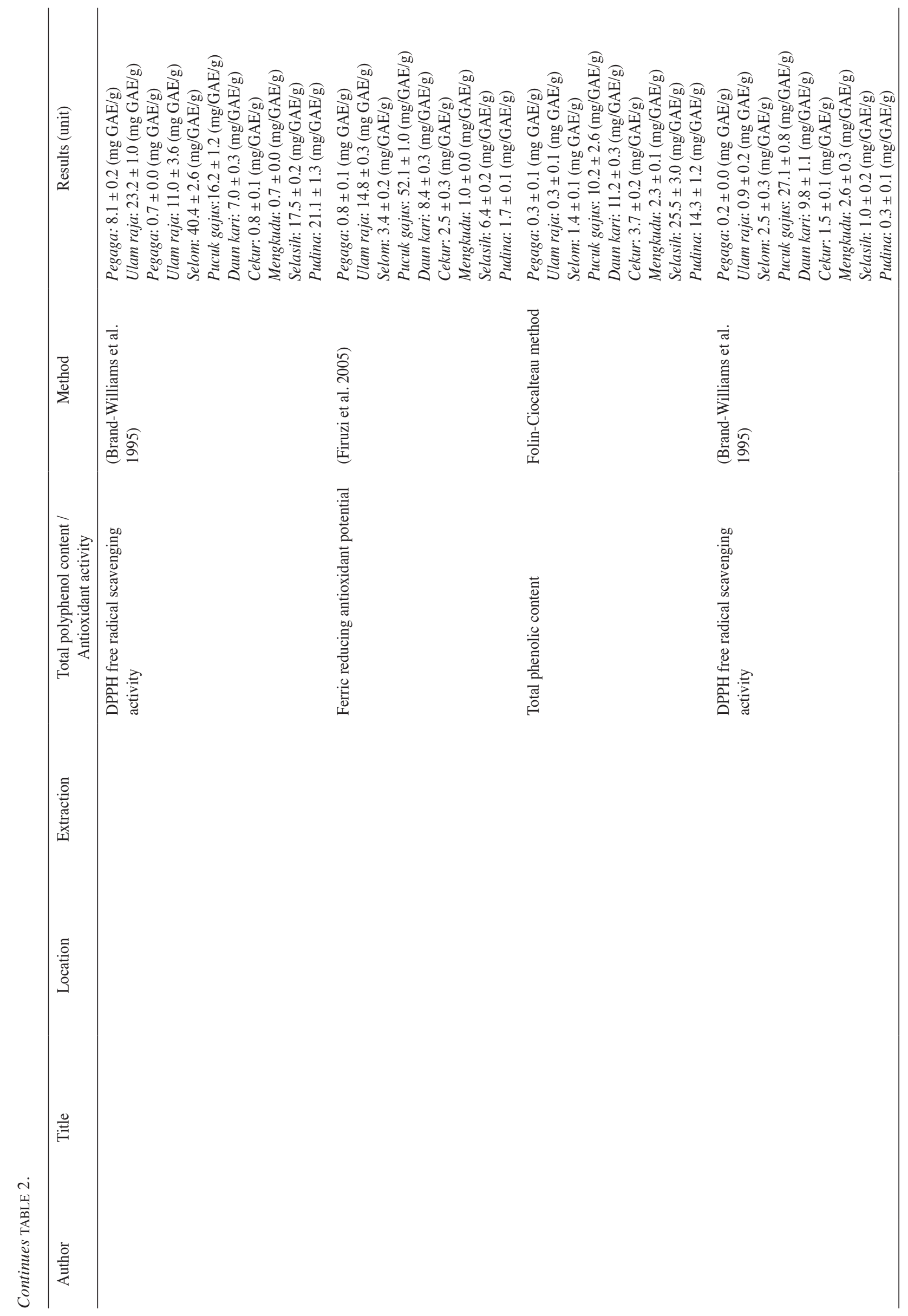




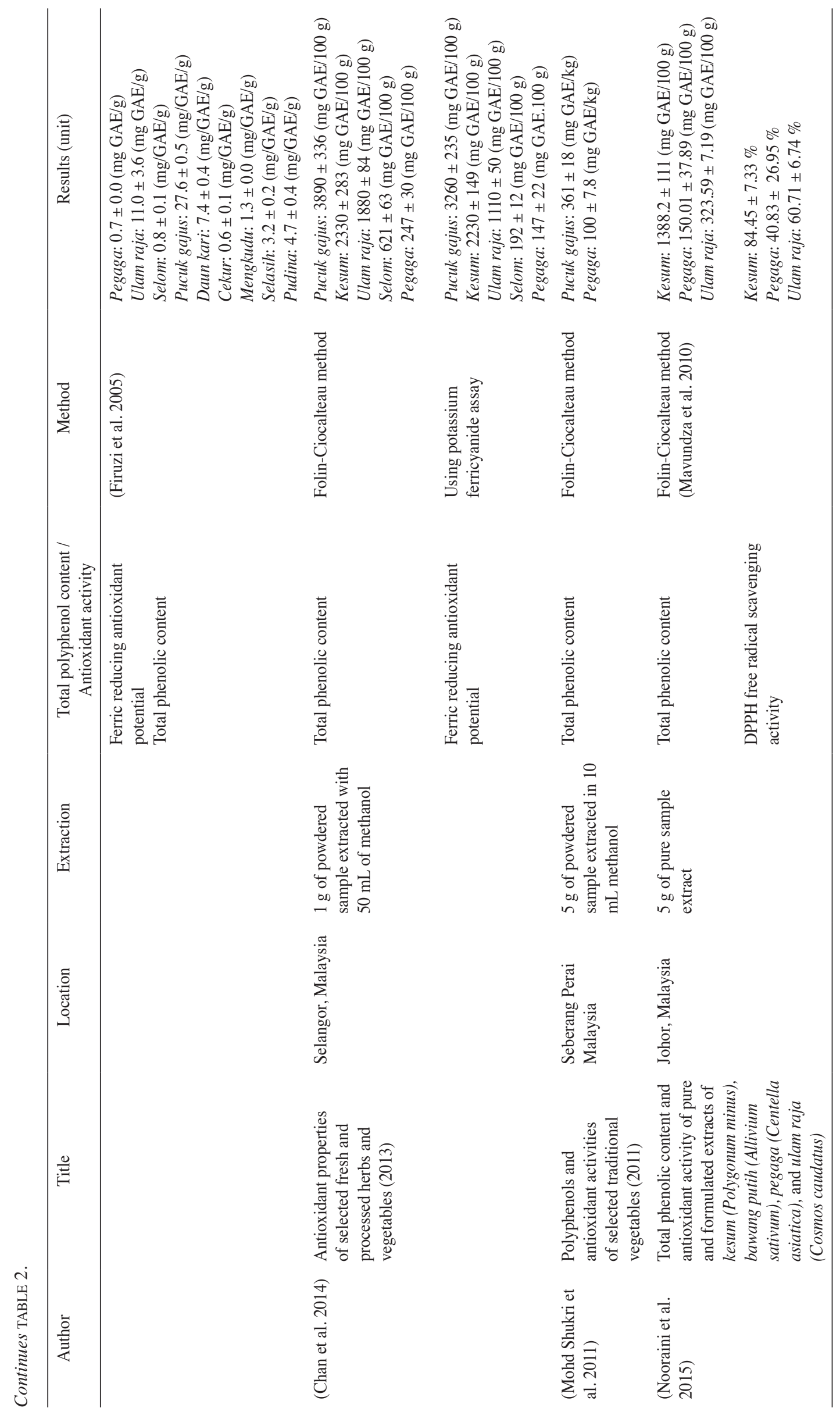




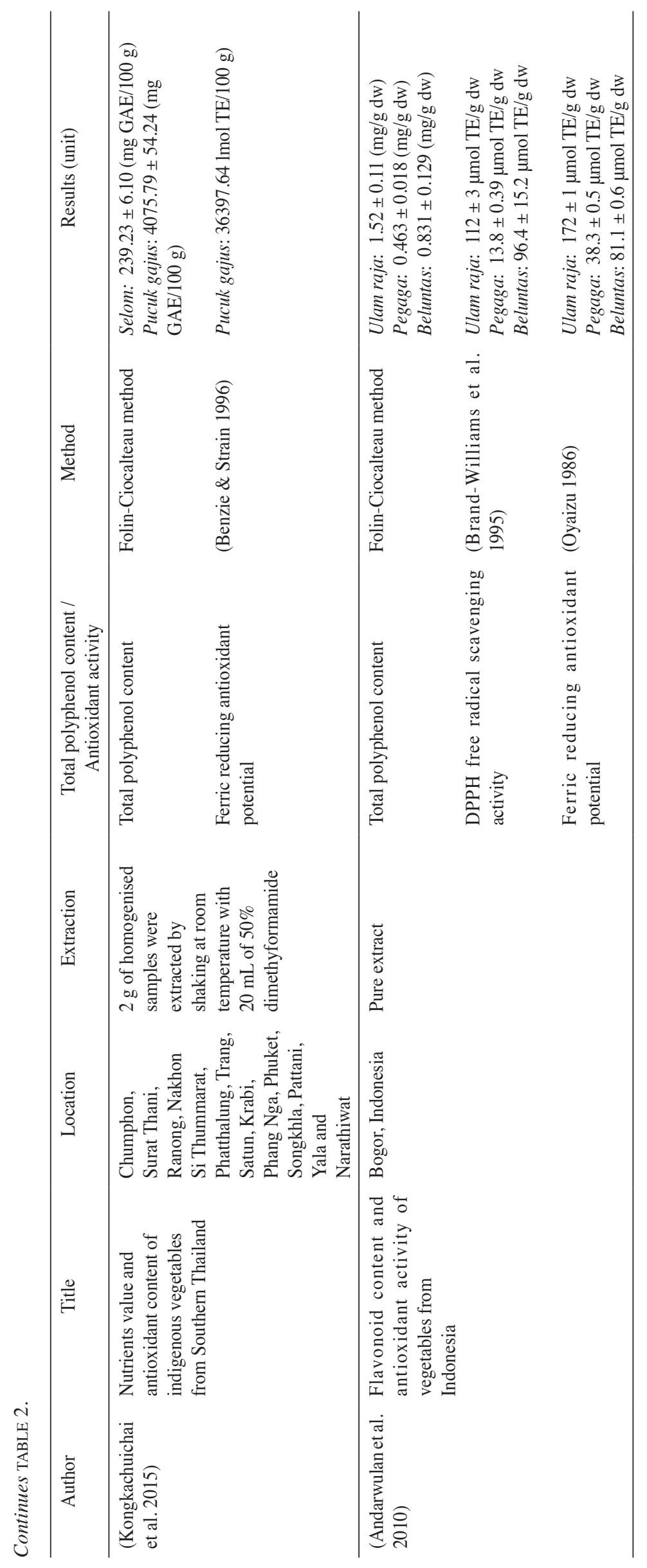


et al. 1998). Sulaiman et al. (2011) reported that kesum has the highest DPPH radical scavenging activity followed by pegaga and ulam raja. The correlation between total phenolic content and antioxidant activity was rather weak $(r=0.293)$ as phenolic compounds were not the only contributor to antioxidant activities. Furthermore, the type, quantity of phenolic compounds and the non-phenolic antioxidants may also affect the antioxidant activity of the plant extracts.

Mediani et al. (2014) has explained the central importance of drying methods in preserving the phytochemical compounds of ulam raja. The drying step prior to storage is necessary to maintain the quality of the herbs. The results indicated the variation of the TPC and antioxidant activity in the samples prepared by air drying, freeze drying and oven drying. In this study, air drying had the minimum influence on the phytochemical compounds, thus, can be applied for the sample preparation due to the acceptable levels of TPC and antioxidant activity and its low cost. Air drying method resulted in the highest free radical scavenging activity against 1,1-diphenyl-2-picrylhydrazyl (DPPH) $(\mathrm{IC} 50=0.0223 \mathrm{mg} / \mathrm{mL})$ and TPC $(27.4 \mathrm{~g} \mathrm{GAE} / 100 \mathrm{~g})$.

The effects of various food processing methods on the antioxidant properties of selected herbs and vegetables were analyzed and evaluated in one of Malaysian study (Chan et al. 2014). It was based on the DPPH radical scavenging activity. Processing methods applied on the tested ulam samples were blanching, microwaving, freezing, brining, and pickling. Among 10 fresh ulam assessed, the pucuk gajus showed the strongest antioxidant properties followed by kesum and ulam raja, selom and pegaga. Generally, kesum, pucuk gajus and ulam raja exhibited high DPPH radical scavenging activity among all selected ulam.

Ferric ion reducing activity of selected ulam Ferric reducing antioxidant power (FRAP) assay is usually carried out using the method described by Benzie and Strain (1996) as a measure of antioxidant power of ulam extracts. When ferric chloride reacts with 2,4,6-tripyridyl-s-triazine (TPTZ) at low pH level, ferric will be converted into ferrous causing formation of ferrous tripyridyl triazine complex. FRAP values are obtained by comparing the absorbance change at $593 \mathrm{~nm}$ in reaction mixture with those containing ferrous ions in known concentration. An antioxidant can prevent the generation of reactive oxygen species by metal chelation or enzyme-catalyzed removal of a potential oxidant in a redox reaction (Benzie \& Strain 1999). In Reihani and Azhar (2012) study, it was reported that selom exhibited the highest ferric ion reducing activity followed by ulam raja, daun kari, pegaga and petai.

In Chan et al. (2014) study, pucuk gajus exhibited the strongest ferric reducing antioxidant potential followed by kesum, ulam raja, selom and pegaga. The ranking results were similar to the TPC. The highest correlation between total phenolic content and FRAP could be obtained from $70 \%$ methanol extracts. This $70 \%$ methanol is the most appropriate solvent for extracting phenolic compounds with FRAP property of ulam (Thaipong et al. 2006) study.
In Sulaiman et al. (2011) study, the ferric ion reducing potential of $70 \%$ methanol extracts can be ranked in the following order: pucuk gajus, ulam raja, daun kari, daun selasih, selom, cekur, daun pudina, mengkudu and pegaga. In general, pucuk gajus exhibited the highest ferric ion reducing potential among all the selected ulam.

Role of polyphenols in improving cognitive decline The role of polyphenols in improving cognitive decline is shown in Figure 2. Cognitive decline is one of the alarming health issues which may cause dementia, illness and death. The cognitive decline may initiate from middleaged onwards or even earlier (Deary et al. 2009). Aging is the strongest factor that causes cognitive decline. The most common brain changes that occur during aging is decreasing in white matter density and number of white matter lesions (Bartzokis 2003; Guttmann et al. 1998). Abnormalities of white matter are associated with reduced performance in processing speed, executive functions and immediate and delayed memory (Gunning-Dixon \& Raz 2000). Oxidative stress is essentially an imbalance between the production of free radicals and the ability of the body to counteract or detoxify their harmful effects through neutralization by antioxidants and polyphenols (McCord 2000). A free radical is an oxygen containing molecule that has one or more unpaired electrons, making it highly reactive with other molecules. Oxygen by-products are relatively unreactive but some of these can undergo metabolism within the biological system to give rise to these highly reactive oxidants called reactive oxygen species (Gilgun-Sherki et al. 2001). However, free radicals can chemically interact with cell components such as DNA, protein or lipid and steal their electrons in order to become stabilized (Pham-Huy et al. 2008). Thus, it will eventually cause DNA damage, protein damage and lipid peroxidation. DNA damage will induce Cytochrome $\mathrm{C}$ release from damaged mitochondria, which will bind to apoptosis-activating factor-1 (Apaf-1) and causing activation of caspases and eventually apoptosis occurs (Schimmer et al. 2004). Prolong DNA damage can cause cognitive impairment among mild cognitive impairment (MCI) and Alzheimer's disease (AD) patient by oxidation of purines and pyrimidine in peripheral neurons. The single and double strands of primary DNA will be broken at the purine and pyrimidine structures as reported among MCI and $\mathrm{AD}$ patients compared to the healthy elderly population (Cooke 2006).

Oxidative stress may be one of factors of neurodegeneration in AD brains (Mao \& Reddy 2011). Generation of oxidative stress is normally due to imbalance between reactive oxygen species (ROS) producing pathways and (ROS)-scavenging pathways. Normally, the ROS production is due to mitochondria dysfunction (Navarro \& Boveris 2008). Mitochondrion is one of the important organelle in aging and some comorbidities including cancer, diabetes, cardiovascular and neurodegenerative diseases (Martin 2010; Reddy 2008). 


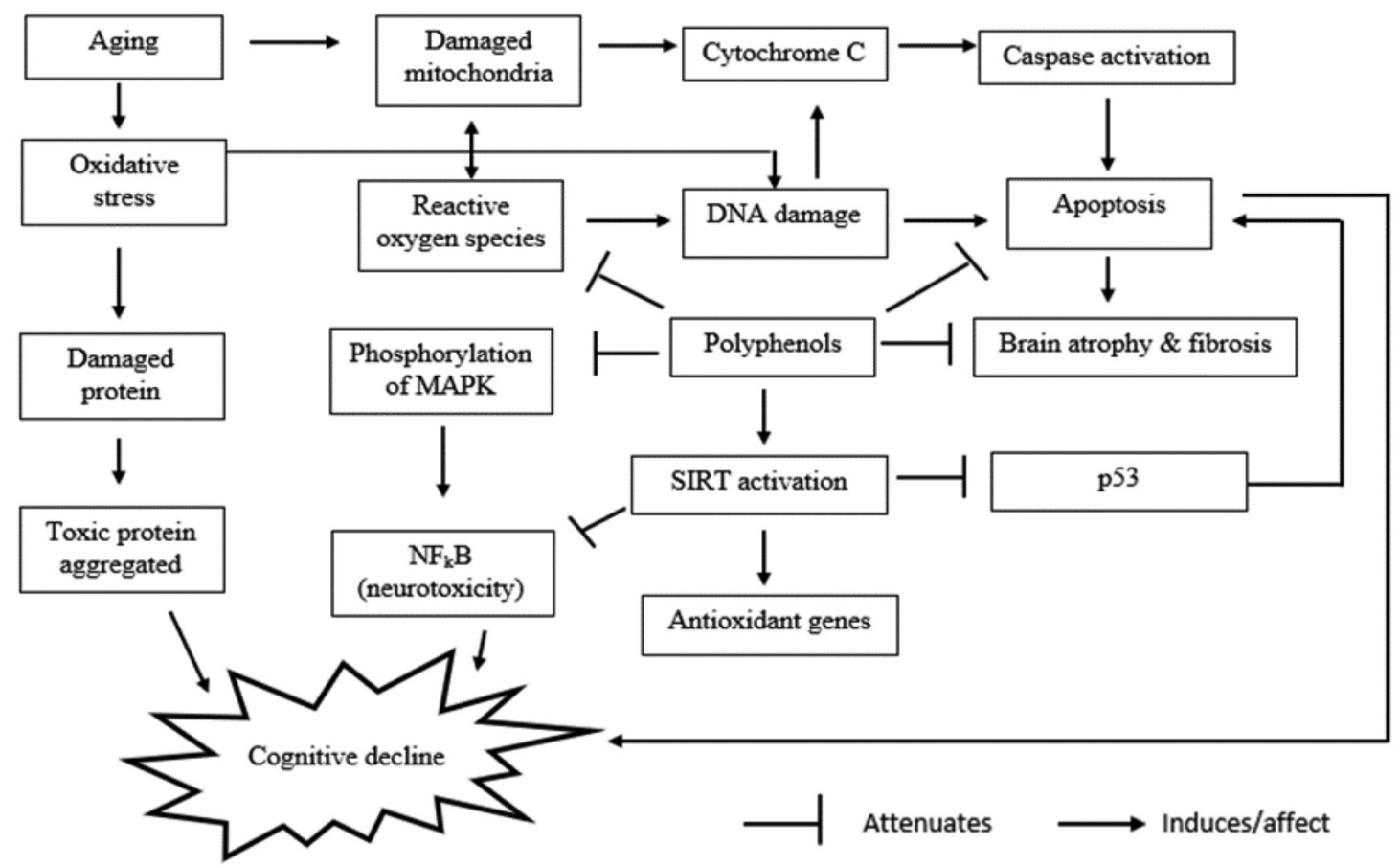

FIGURE 2. Brief diagram on the process leading to cognitive decline associated with polyphenols

Mitochondria dysfunction will cause reactive oxygen species (ROS) production, abnormal intracellular calcium levels and reduced in mitochondrial ATP (Hengartner 2000). Mutation of mitochondria DNA (mtDNA) structure can be seen among AD patients which is caused by misreading of oxidized bases during DNA replication process and it leads to nucleotide substitution. Eventually it will cause neuropathological changes in AD patients' brain and lead to severe neurodegenerative disease condition. If the number of mtDNA increases, it will cause mitochondria dysfunction and eventually lead to high ROS production. The increased generation of ROS can cause lipid peroxidation, protein damage, and several types of DNA lesions in cells (Lagouge \& Larsson 2013). Mitochondria dysfunction will cause protein releases from the mitochondria that activate the caspase pathway leading to apoptosis, cell death and aging (Lagouge \& Larsson 2013). Thus, this will then lead to Alzheimer's disease and other neurodegenerative diseases.

Inadequate polyphenols and antioxidants intake, iron overload, insulin resistance and aging are factors causing mitochondria dysfunction and oxidative stress among elderly population (Roussel \& Ferry 2002). Aging process is a progressive condition that will cause the accumulation of oxidative damage to biomolecules such as nucleic acids, lipids, proteins and carbohydrates due to imbalance between pro-oxidants and antioxidants. Individuals with mild cognitive impairment may show high oxidative damage in the brain before the onset of dementia (Hedden \& Gabrieli 2004).

On the other hand, polyphenols can cause sirtuins activation. Sirtuins is a type of protein which is encoded by a gene. They act as cell regulators in human body and play an important role in attenuating neurodegenerative diseases. Sirtuins is also called NAD-dependent deacetylase sirtuin-1 which is an enzyme that deacetylates proteins that contribute to cellular regulation in humans (Sinclair \& Guarente 2006). Sirtuins specifically SIRT 1 can inhibit NF$\mathrm{kB}$-regulated gene expression which is a protein complex strongly linked to aging, degenerative disorders and even cancer. SIRT 1 is responsible in deacetylation of p53 which will reduce the tendency of apoptosis of cells when exposed to damage (Sinclair \& Guarente 2006). Furthermore, Nuclear factor kappa-light-chain-enhancer of activated B cells $(\mathrm{NF}-\mathrm{\kappa B})$-regulated gene expression is inhibited by deacetylating the RelA/p65 subunit of NF- $\mathrm{kB}$ at lysine 310 and SIRT1 activation (Kauppinen et al. 2013; Yeung et al. 2004). NF- $\kappa \mathrm{B}$ is a protein which controls transcription of DNA and many genes involved in inflammation and high NF- $\kappa \mathrm{B}$ also could cause schizophrenia due to inflammation and degeneration of neurons (Monaco et al. 2004; Song et al. 2009).

Polyphenol has the potential to inhibit mitogenactivated protein kinase (MAPK) signaling pathway by regulating the expression of inflammatory proteins and cytokines production which induced by lipopolysaccharide (LPS) and the activation of MAPK was reduced (Spagnuolo et al. 2017). MAPK is a type of protein kinase which regulate proliferation, gene expression, differentiation, cell survival and apoptosis (Pearson et al. 2001). The flavonoid could scavenge free radicals and reduce neuron apoptosis so that neuroinflammation is inhibited. One of the study reported that at the doses of $50-200 \mathrm{mg} / \mathrm{kg}$ of flavonoid-rich extract from Rosa laevigata Michx could reduce the pro-inflammatory markers (NF- $\kappa \mathrm{B}$, iNOS, COX- 
2, MMP-9, TNF- $\alpha$, IL-4, IL-6, IL-1 $\beta$ ) expression followed by the reduction of the levels of p-JNK, p-ERK and p38 which involved in MAPK pathway (Zhang et al. 2013). In addition, quercetin, a bioactive compound was able to decrease inducible nitric oxide synthase (iNOS) expression which is involved in the stimulation of nitric oxide (NO) in microglial cells that trigger neurodegenerative disease (Bournival et al. 2012).

Neuroprotective effect of selected ulam Out of eight studies that had been reviewed in Table 3, only two studies were human trials carried out in Malaysia, a study was a systematic review in Thailand and the remaining studies were animal studies $(n=5)$ in Malaysia and Indonesia. In addition, the randomized controlled trial studies involving ulam tablet supplementation to healthy adults and middleaged women and assessed their cognitive function. Poor mental health will affect individuals as their age increases and cause the cognitive function decline.

Study by Udani (2013) reported a significant improvement in executive functioning, cognitive flexibility, reaction time and working memory after the intervention by providing 20 healthy subjects in Malaysia with Superulam capsules for 3 weeks. Superulam capsule is made up of combination extracts sireh, turmeric, pegaga, daun kari, selasih, kesum and ulam raja. When comparing capsule to placebo, the data showed a significant decrease in mood, angerand tension among capsule supplemented subjects (Udani 2013). The study by Shahar et al. (2015) reported that supplementation of two Polygonum minus (kesum) capsules $(250 \mathrm{mg}$ ) taken once daily has the potential to improve mood and quality of life after 6 weeks of intervention compared to baseline among 35 to 55 years old middle-aged women (Shahar et al. 2015; Yahya et al. 2017). This result was supported by George et al. (2014) study which reported that Polygonum minus possesses antioxidant and anticholinesterase activity and demonstrated enhanced cognition in vivo. Cellular antioxidant protection from free radical damage was also observed in mice. Polygonum minus contains two bioactive compounds namely quercetin and quercetin-3-glucuronide which act as anti-depression agent. In one of in vivo studies, it was shown that quercetin could reduce stress-induced brain corticotropin-releasing factor (CRF) expression which would cause anxiety and depression.

Based on the conclusion made by a systematic review in Thailand, due to different doses and standardization of Centella asiatica (pegaga) used in the interventions, no strong evidence can be used to prove that pegaga can improve cognitive function. However, most of the studies reported that pegaga capsule supplementation could improve working memory, alertness and relieve anger. This result was obtained from a systemic review article which reviewed 11 articles related to relationship between pegaga consumption, particularly capsule supplementation with cognitive function and mood (Puttarak et al. 2017). Pegaga had been consumed to control anxiety as it helps in relaxation and mental calmness by inhibiting phospholipase substrate 2 activities in rat's cerebellum (Wijeweera et al. 2006). There are many in vivo studies which studied the central nervous system effects of pegaga but the clinical trials and human studies are still limited (Puttarak et al. 2017; Yogeswaran et al. 2016).

In addition to Polygonum minus and Centella asiatica, Oenanthe javanica leaves or selom has also been studied for its neuroprotective effect. One of the animal study indicated that Oenanthe javanica extract could improve cell proliferation and neuroblast differentiation by increasing brain-derived neurotrophic factor immunoreactivity in the rat dentate gyrus (Chen et al. 2015). Oenanthe javanica leaves or selom can be used for the development of products for memory improvement because it could inhibit acetylcholinesterase (AChE) activity and increase latency time in passive avoidance test (Won et al. 2015). In general, further human study on the supplementation of Oenanthe javanica is warranted to study the relationship with human cognitive function. Another 2 animal studies also reported that Murraya koenigii leaves increased acetylcholine level in brain and would improve memory of both young and aged mice (Tembhurne \& Sakarkar 2010). Furthermore, it also could inhibit brain acetylcholinesterase enzyme and elevate the acetylcholine concentration in brain homogenate and also improving memory to prevent Alzheimer's disease (Mani et al. 2012). Ocimum basilicum leaves also reported to have neuroprotective property as it can reduce cerebral infarct size and lipid peroxidation, restoration of glutathione content and prevent Alzheimer's disease in mice (Bora et al. 2011).

\section{FUTURE DIRECTIONS AND RESEARCH GAPS}

Mild-cognitive impairment (MCI) is known to be intermediate stage between aging and dementia. Those populations with MCI have a high risk of developing dementia (Burns \& Zaudig 2002). Individuals with dementia and Alzheimer's disease in the world are estimated to be doubled for every 20 years and reached 81 million by 2040 (Reitz et al. 2011). There are limited pharmacological treatment for Alzheimer's-related memory loss and dementia, thus it is important to assess the cognitive impairment at an early stage and exploring treatment and prevention measures are very crucial. In this review, ulam had been shown to be rich in polyphenols and antioxidants (Amalia et al. 2012; Bachok et al. 2014). To date, most studies were animal studies $(n=5)$ and the limited human-based studies $(n=3)$ resulted in inadequate evidence-based conclusions in the effects neuroprotective effects of ulam (Yogeswaran et al. 2016). Majority of studies used ulam tablet supplementation which needs higher financial resources, however less effective for long term measure. On the other hand, the consumption of ulam in raw form which is cheaper and more effective for long term measure (Nyaw \& Nyaw 2010). In addition, although many studies conducted in the South East Asia have determined the TPC and antioxidant activities of ulam, the study on the relationship between the TPC and 


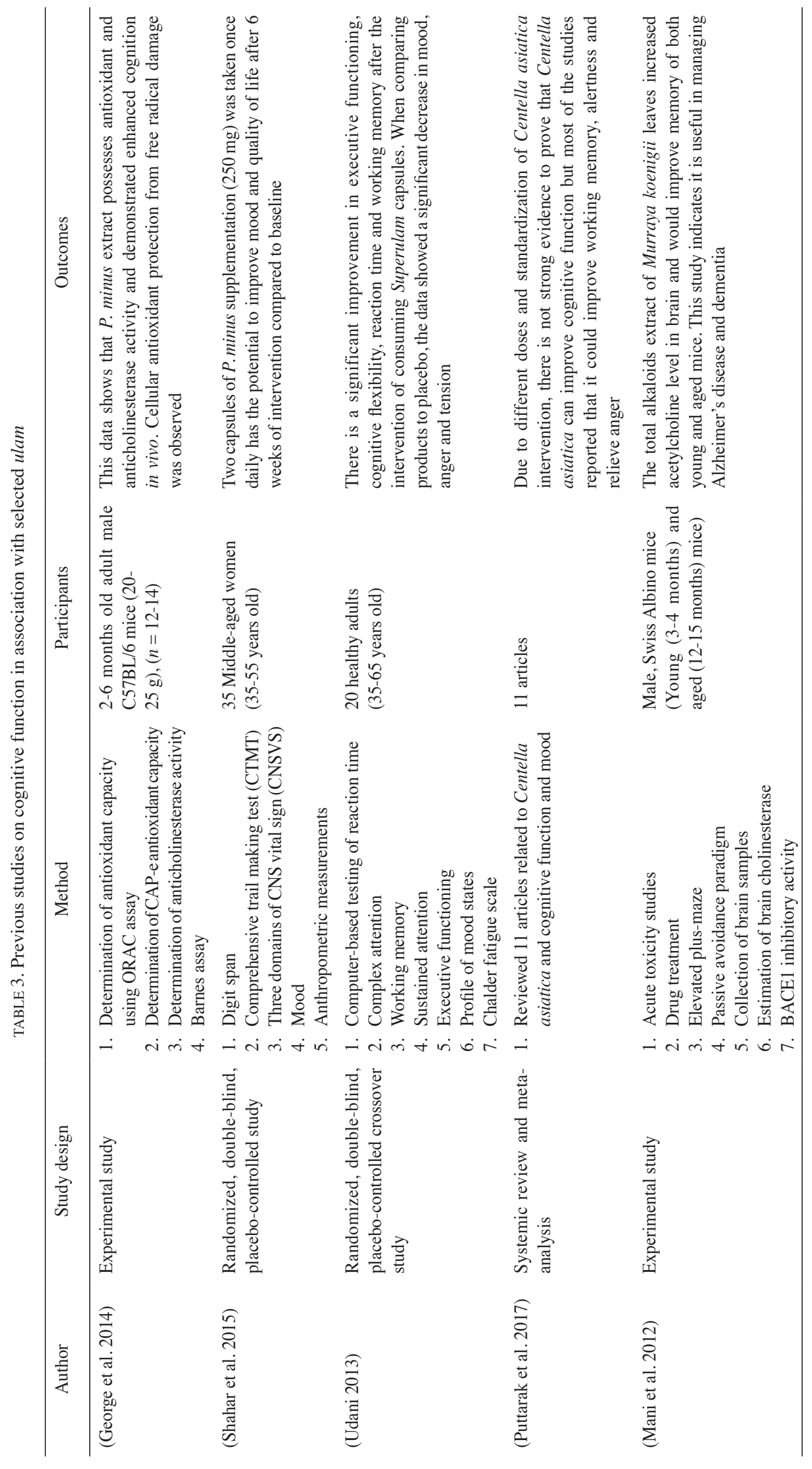




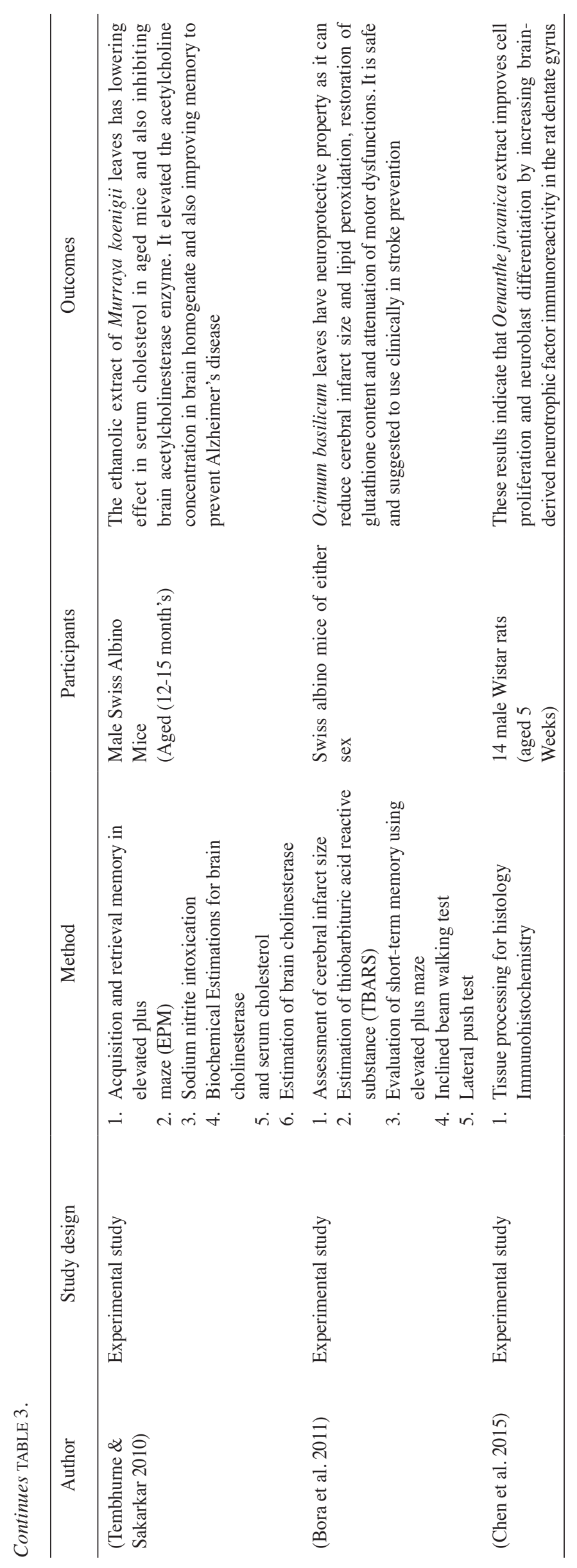


antioxidant activity of ulam with cognitive status is still lacking. Therefore, it is crucial to conduct human studies to determine the effectiveness of polyphenol rich ulam that can contribute to reduction of cognitive decline. Biofluid samples including urine, blood and faeces may be collected and analyzed using metabolic profiling methods to discover the novel biomarkers of ulam intake and cognitive function-associated metabolites. The results of this study will identify the high potential ulam to be incorporated in the daily diet in order to prevent or manage symptoms and problems related to poor mental health and cognitive function. There is a potential for ulam to be commercialised as fortified food products in order to increase its outreach in global market.

\section{CONCLUSION}

In this review, traditional vegetables or ulam was found to be rich in polyphenols, antioxidants and contains medicinal properties such as neuroprotective effect. Centella asiatica (pegaga), Oenanthe javanica (selom), Polygonum minus (kesum), Ocimum basilicum (daun selasih) and Murraya koenigii (daun kari) have the potential to improve cognitive function and mood improvement but more clinical studies should be undertaken to confirm the role of these ulam and others as neuroprotective agent.

\section{ACKNOWLEDGEMENTS}

Gratitude is expressed to the contribution, support and assistance of all co-authors in reviewing and writing this review article which is supported by the Dana Padanan Kolaborasi research grant (DPK-2017-004).

\section{REFERENCES}

Amalia, L., Anggadired, K., Sukrasno, Fidrianny, I. \& Inggriani, R. 2012. Antihypertensive potency of wild cosmos (Cosmos caudatus Kunth, Asteraceae) leaf extract. Journal of Pharmacology and Toxicology 7(8): 359-368.

Andarwulan, N., Batari, R., Sandrasari, D.A., Bolling, B. \& Wijaya, H. 2010. Flavonoid content and antioxidant activity of vegetables from Indonesia. Food Chemistry 121(4): 1231-1235.

Bachok, M.F., Yusof, B.N.M., Ismail, A. \& Hamid, A.A. 2014. Effectiveness of traditional Malaysian vegetables (ulam) in modulating blood glucose levels. Asia Pacific Journal of Clinical Nutrition 23(3): 369-376.

Bartzokis, G. 2003. Myelination and brain electrophysiology in healthy and schizophrenic individuals. Neuropsychopharmacology 28(6): 1217-1218. doi:10.1038/ sj.npp.1300180.

Benzie, I.F.F. \& Strain, J.J. 1999. Ferric reducing/antioxidant power assay: Direct measure of total antioxidant activity of biological fluids and modified version for simultaneous measurement of total antioxidant power and ascorbic acid concentration. Methods in Enzymology 299: 15-27.

Benzie, I.F.F. \& Strain, J.J. 1996. The ferric reducing ability of plasma (FRAP) as a measure of "Antioxidant Power": The FRAP assay. Analytical Biochemistry 239(1): 70-76.
Bora, K.S., Arora, S. \& Shri, R. 2011. Role of Ocimum basilicum L. in prevention of ischemia and reperfusion-induced cerebral damage, and motor dysfunctions in mice brain. Journal of Ethnopharmacology 37(3): 1360-1365.

Bournival, J., Plouffe, M., Renaud, J., Provencher, C. \& Martinoli, M.G. 2012. Quercetin and sesamin protect dopaminergic cells from MPP+-induced neuroinflammation in a microglial (N9)-neuronal (PC12) coculture system. Oxidative Medicine and Cellular Longevity 2012: 921941.

Brand-Williams, W., Cuvelier, M.E. \& Berset, C. 1995. Use of a free radical method to evaluate antioxidant activity. $L W T$ Food Science and Technology 28(1): 25-30.

Burns, A. \& Zaudig, M. 2002. Mild cognitive impairment in older people. The Lancet 360: 1963-1965.

Chan, E.W.C., Tan, Y.P., Chin, S.J., Gan, L.Y., Kang, K.X., Fong, C.H., Chang, H.Q. \& How, Y.C. 2014. Antioxidant properties of selected fresh and processed herbs and vegetables. Free Radicals and Antioxidants 4(1): 39-46.

Chen, B.H., Park, J.H., Cho, J.H., Kim, I.H., Shin, B.N., Ahn, J.H., Hwang, S.J., Bing, C.Y., Tae, H.J., Lee, J.C., Bae, E.J., Lee, Y.L., Kim, J.D., Won, M.H. \& Kang, I.J. 2015. Ethanol extract of Oenanthe javanica increases cell proliferation and neuroblast differentiation in the adolescent rat dentate gyrus. Neural Regeneration Research 10(2): 271-276.

Cooke, M. 2006. Silicon transistor hits $500 \mathrm{GHz}$ performance. III-Vs Review 19(5): 30-31.

Deary, I.J., Corley, J., Gow, A.J., Harris, S.E., Houlihan, L.M., Marioni, R.E., Penke, L., Rafnsson, S.B. \& Starr, J.M. 2009. Age-associated cognitive decline. British Medical Bulletin 92(1): 135-152.

Escarpa,A. \& González, M. 2001 . Approach to the content of total extractable phenolic compounds from different food samples by comparison of chromatographic and spectrophotometric methods. Analytica Chimica Acta 427(1): 119-127.

Firuzi, O., Lacanna, A., Petrucci, R., Marrosu, G. \& Saso,L. 2005. Evaluation of the antioxidant activity of flavonoids by "ferric reducing antioxidant power" assay and cyclic voltammetry. Biochimica et Biophysica Acta - General Subjects 1721(13): 174-184.

Fokkens, W., Lund, V., Bachert, C. \& Clement, P. 2005. European position paper on rhinosinusitis and nasal polyps. Rhinology. http://bib.irb.hr/prikazi-rad?rad=221020.

Gambhir, I., Tiwari, S., Singha, S., Patwardhan, K. \& Gehlot, S. 2008. Effect of Centella asiatica on mild cognitive impairment (MCI) and other common age-related clinical problems. Digest Journal of Nanomaterials and Biostructures 3(4): 215-220.

George, A., Ng, C.P., Callaghan, M.O., Jensen, G.S. \& Wong, H.J. 2014. In vitro and ex-vivo cellular antioxidant protection and cognitive enhancing effects of an extract of Polygonum minus Huds (Lineminus ${ }^{\mathrm{TM}}$ ) demonstrated in a Barnes Maze animal model for memory and learning. BMC Complement. Altern. Med. 14: 161.

George, A., Ng, C.P., O'Callaghan, M., Jensen, G.S. \& Wong, H.J., Gilgun-Sherki, Y., Melamed, E. \& Offen, D. 2001. Oxidative stress induced-neurodegenerative diseases: The need for antioxidants that penetrate the blood brain barrier. Neuropharmacology 40(8): 959-975. doi:10.1016/S00283908(01)00019-3.

Gunning-Dixon, F.M. \& Raz, N. 2000. The cognitive correlates of white matter abnormalities in normal aging: A quantitative review. Neuropsychology 14(2): 224-232. 
Guttmann, C.R., Jolesz, F.A., Kikinis, R., Killiany, R.J., Moss, M.B., Sandor, T. \& Albert, M.S. 1998. White matter changes with normal aging. Neurology 50(4): 972-978.

Hedden, T. \& Gabrieli, J.D.E. 2004. Insights into the ageing mind: A view from cognitive neuroscience. Nature Reviews Neuroscience 5(2): 87-96.

Hengartner, M.O. 2000. The biochemistry of apoptosis. Nature 407(6805): 770-776.

Huda-Faujan, N., Noriham, A., Norrakiah, A.S. \& Babji, A.S. 2007. Antioxidative activities of water extracts of some Malaysian herbs. International Food Research Journal 14(1): 61-68.

Institute for Public Health. 2015. National Health and Morbidity Survey 2015 (NHMS 2015). Vol. II: Non-Communicable Diseases, Risk Factors \& Other Health Problems. Ministry of health, hlm.Vol. II. doi:10.1017/CBO9781107415324.004.

Izunya, A.M., Oaikhena, G.A., Bankole, J.K., Ogarah, P.A. \& State, E. 2010. Morphological and biochemical effects of crude aqueous extract of Mangifera indica L. (Mango) stem bark on the liver in wistar rats. Engineering and Technology 2(5): 460-465.

Kauppinen, A., Suuronen, T., Ojala, J., Kaarniranta, K. \& Salminen, A. 2013. Antagonistic crosstalk between NF- $\kappa B$ and SIRT1 in the regulation of inflammation and metabolic disorders. Cellular Signalling 25(10): 1939-1948.

Kongkachuichai, R., Charoensiri, R., Yakoh, K., Kringkasemsee, A. \& Insung, P. 2015. Nutrients value and antioxidant content of indigenous vegetables from Southern Thailand. Food Chemistry 173: 836-846.

Lagouge, M. \& Larsson, N.G. 2013. The role of mitochondrial DNA mutations and free radicals in disease and ageing. Journal of Internal Medicine 273(6): 529-543.

Maizura, M.,Aminah, A. \& Wan Aida, W.M. 2011. Total phenolic content and antioxidant activity of kesum (Polygonum minus), ginger (Zingiber officinale) and turmeric (Curcuma longa) extract. International Food Research Journal 18: 529-534.

Mani, V., Ramasamy, K., Ahmad, A., Parle, M., Shah, S.A.A. \& Majeed, A.B.A. 2012. Protective effects of total alkaloidal extract from Murraya koenigii leaves on experimentally induced dementia. Food and Chemical Toxicology 50(3-4): 1036-1044.

Mao, P. \& Reddy, P.H. 2011. Aging and amyloid beta-induced oxidative DNA damage and mitochondrial dysfunction in Alzheimer's disease: Implications for early intervention and therapeutics. Biochimica et Biophysica Acta 1812(11): 1359-1370.

Martin, L.J. 2010. Mitochondrial and cell death mechanisms in neurodegenerative diseases. Pharmaceuticals (Basel, Switzerland) 3(4): 839-915.

Mavundza, E.J., Tshikalange, T.E., Lall, N., Hussein, A.A., Mudau, F.N. \& Meyer, J.J.M. 2010. Antioxidant activity and cytotoxicity effect of flavonoids isolated from athrixia phylicoides. Journal of Medicinal Plants Research 4(23): 2584-2587.

McCord, J.M. 2000. The evolution of free radicals and oxidative stress. American Journal of Medicine 108(8): 652-659.

Mediani, A., Abas, F., Tan, C. \& Khatib, A. 2014. Effects of different drying methods and storage time on free radical scavenging activity and total phenolic content of Cosmos caudatus. Antioxidants 3(2): 358-370.

Mohd Akhtar, Ahmad, M.A., Sumbul, S. \& Mohd Asif. 2011. Role of phenolic compounds in peptic ulcer: An overview. Journal of Pharmacy and Bioallied Sciences 3(3): 361. doi:10.4103/0975-7406.84437.
Mohd Shukri, M.A., Alan, C. \& Siti Noorzuraini, A.R. 2011. Polyphenols and antioxidant activities of selected traditional vegetables. Journal of Tropical Agriculture and Food Science 39(203): 69-83

Monaco, C., Andreakos, E., Kiriakidis, S., Mauri, C., Bicknell, C., Foxwell, B., Cheshire, N. Paleolog, E. \& Feldmann, M. 2004. Canonical pathway of nuclear factor kappa B activation selectively regulates proinflammatory and prothrombotic responses in human atherosclerosis. Proceedings of the National Academy of Sciences of the United States of America 101(15): 5634-5639.

National Coordinating Committee on Food and Nutrition. Ministry of Health Malaysia. 2010. Malaysian Dietary Guidelines. Putrajaya: Ministry of Health Malaysia. http:// www.moh.gov.my/images/gallery/Garispanduan/diet/ introduction.pdf. hlm.Vol. 1.

Navarro, A. \& Boveris, A. 2008. Mitochondrial nitric oxide synthase, mitochondrial brain dysfunction in aging, and mitochondria-targeted antioxidants. Advanced Drug Delivery Reviews 60(13-14): 1534-1544.

Nooraini, Z., Sayang, B., Ku Nurul Aqmar, K.B.\& Salehhuddin, H. 2015. Total phenolic content and antioxidant activity of pure and formulated extracts of kesum (Polygonum minus), bawang putih (Allivium sativum), pegaga (Centella asiatica), and ulam. Malaysian Journal of Fundamental and Applied Sciences 11(4): 179-183.

Nurul Izzah, A., Aminah, A., Md Pauzi, A., Lee, Y.H., Wan Rozita, W.M. \& Fatimah, S. 2012. Patterns of fruits and vegetable consumption among adults of different ethnics in Selangor, Malaysia. International Food Research Journal 19(3): 1095-1107.

Nyaw, B.F.M.K. \& Nyaw, M.K. 2010. Enriching Lives: A History of Insurance in Hong Kong. Hong Kong Scholarship Online. doi: 10.5790/hongkong/9789888028702.001.0001.

Oyaizu, M. 1986. Studies on products of browning reaction. Antioxidative activities of products of browning reaction prepared from glucosamine. The Japanese Journal of Nutrition and Dietetics 44(6): 307-315.

Pearson, G., Robinson, F., Beers Gibson, T., Xu, B.E., Karandikar, M., Berman, K. \& Cobb, M.H. 2001. Mitogenactivated protein (MAP) kinase pathways: Regulation and physiological functions. Endocrine Reviews 22: 153-183.

Petersen, R.C., Caracciolo, B., Brayne, C., Gauthier, S., Jelic, V. \& Fratiglioni, L. 2014. Mild cognitive impairment: A concept in evolution. Journal of Internal Medicine 275(3): 214-228.

Pham-Huy, L.A., He, H. \& Pham-Huy, C. 2008. Free radicals, antioxidants in disease and health. International Journal of Biomedical Science: IJBS 4(2): 89-96.

Prince, M., Bryce, R., Albanese, E., Wimo, A., Ribeiro, W. \& Ferri, C.P. 2013. The global prevalence of dementia: A systematic review and metaanalysis. Alzheimer's and Dementia 9(1): 63-75.

Puttarak, P., Dilokthornsakul, P., Saokaew, S., Dhippayom, T., Kongkaew, C., Sruamsiri, R., Chuthaputti, A. \& Chaiyakunapruk, N. 2017. Effects of Centella asiatica (L.) Urb. on cognitive function and mood related outcomes: A Systematic review and meta-analysis. Scientific Reports 7(1). doi:10.1038/s41598-017-09823-9.

Reddy, P.H. 2008. Mitochondrial medicine for aging and neurodegenerative diseases. NeuroMolecular Medicine 10(4): 291-315. 
Reihani, S.F.S. \& Azhar, M.E. 2012.Antioxidant activity and total phenolic content in aqueous extracts of selected traditional Malay salads (Ulam). International Food Research Journal 19(4): 1439-1444.

Reitz, C., Brayne, C. \& Mayeux, R. 2011. Epidemiology of Alzheimer disease. Nature Reviews Neurology 7(3): 137-152.

Rosli, H., Shahar, S., Che Din, N. \& Haron, H. 2014. Dietary polyphenols consumption and its relation with cognitive and mental health in aging: A review. Jurnal Sains Kesihatan Malaysia 12(2). doi:10.17576/jskm-2014-1202-01.

Roussel,A.M. \& Ferry, M. 2002. Stress oxydant et vieillissement - Oxidative stress, nutrition and aging. Cancer Research 16: 285-291.

Schimmer, A.D., Welsh, K., Pinilla, C., Wang, Z., Krajewska, M., Bonneau, M.J., Pedersen, I.M., Kitada, S., Scott, F.L., Bailly-Maitre, B., Glinsky, G., Scudiero, D., Sausville, E., Salvesen, G., Nefzi, A., Ostresh, J.M., Houghten, R.A. \& Reed, J.C. 2004. Small-molecule antagonists of apoptosis suppressor XIAP exhibit broad antitumor activity. Cancer Cell 5(1): 25-35.

Shahar, S., Aziz, A.F., Ismail, S.N.A., Yahya, H.M., Din, N.C., Manaf, Z.A. \& Badrasawi, M.M. 2015. The effect of Polygonum minus extract on cognitive and psychosocial parameters according to mood status among middle-aged women: A randomized, double-blind, placebo-controlled study. Clinical Interventions in Aging 10: 1505-1520.

Sinclair, D.A. \& Guarente, L. 2006. Unlocking the secrets of longevity genes. Sci. Am. 294(3): 48-57.

Singleton, V.L., Orthofer, R. \& Lamuela-Raventós, R.M. 1998. Analysis of total phenols and other oxidation substrates and antioxidants by means of folin-ciocalteu reagent. Methods in Enzymology 299(1974): 152-178.

Solomon, P.R., Adams, F., Silver, A., Zimmer, J. \& DeVeaux, R. 2002. Ginkgo for memory enhancement: A randomized controlled trial. JAMA: The Journal of the American Medical Association 288(7) 835-840.

Song, X.Q., Lv, L.X., Li, W.Q., Hao, Y.H. \& Zhao, J.P. 2009. The interaction of nuclear factor-kappa $\mathrm{b}$ and cytokines is associated with schizophrenia. Biological Psychiatry 65(6): 481-488.

Spagnuolo, C., Moccia, S. \& Russo, G.L. 2017. Antiinflammatory effects of flavonoids in neurodegenerative disorders. European Journal of Medicinal Chemistry. doi:10.1016/j.ejmech.2017.09.001.

Su, L.J. \& Arab, L. 2006. Salad and raw vegetable consumption and nutritional status in the adult US population: Results from the third national health and nutrition examination survey. Journal of the American Dietetic Association 106(9): 1394-1404.

Sulaiman, S.F., Yusoff, N.A.M., Eldeen, I.M., Seow, E.M., Sajak, A.A.B., Supriatno \& Ooi, K.L. 2011. Correlation between total phenolic and mineral contents with antioxidant activity of eight Malaysian bananas (Musa sp.). Journal of Food Composition and Analysis 24(1): 1-10.

Tembhurne, S.V. \& Sakarkar, D.M. 2010. Beneficial effects of ethanolic extract of Murraya koenigii (Linn) leaves in cognitive deficit aged mice involving possible anticholinesterase and cholesterol lowering mechanism. International Journal of PharmTech Research 2(1): 181-188.

Thaipong, K., Boonprakob, U., Crosby, K., Cisneros-Zevallos, L. \& Hawkins Byrne, D. 2006. Comparison of ABTS, DPPH, FRAP, and ORAC assays for estimating antioxidant activity from guava fruit extracts. Journal of Food Composition and Analysis 19(6-7): 669-675.

Udani, J.K. 2013. Effects of superulam on supporting concentration and mood: A randomized, double-blind, placebo-controlled crossover study. Evidence-based Complementary and Alternative Medicine 2013: 238454

Vanoh, D., Shahar, S., Din, N.C., Omar, A., Vyrn, C.A., Razali, R., Ibrahim, R. \& Tengku Aizan Hamid. 2017. Predictors of poor cognitive status among older Malaysian adults: baseline findings from the LRGS TUA cohort study. Aging Clinical and Experimental Research 29(2): 173-182.

Wijeweera, P., Arnason, J.T., Koszycki, D. \& Merali, Z. 2006. Evaluation of anxiolytic properties of Gotukola - (Centella asiatica) extracts and asiaticoside in rat behavioral models. Phytomedicine 13(9-10): 668-676.

Won, B.Y., Shin, K.Y., Ha, H.J., Chang, K.A., Yun, Y.S., Kim, Y.R., Park, Y.J. \& Lee, H.G. 2015. Effect of dropwort (Oenanthe javanica) extracts on memory improvement in Alzheimer's disease animal model, Tg2576 mice. Korean Journal of Food Science and Technology 47(6): 779-784.

Wong, S.P., Leong, L.P. \& William Koh, J.H. 2006. Antioxidant activities of aqueous extracts of selected plants. Food Chemistry 99(4): 775-783.

Yahya, H.M., Shahar, S., Arina Ismail, S.N., Aziz, A.F., Din, N.C. \& Abdul Hakim, B.N. 2017. Mood, cognitive function and quality of life improvements in middle aged women following supplementation with Polygonum minus extract. Sains Malaysiana 46(2): 245-254.

Yeung, F., Hoberg, J.E., Ramsey, C.S., Keller, M.D., Jones, D.R., Frye, R.A. \& Mayo, M.W. 2004. Modulation of NF$\kappa \mathrm{B}$-dependent transcription and cell survival by the SIRT1 deacetylase. EMBO Journal 23(12): 2369-2380.

Yogeswaran, L., Norazzila, O., Nur Nabila, A., Aminuddin, S. \& Ruszymah, H. 2016. Recent updates in neuroprotective and neurodegenerative potential of Centella asiatica. Malays $J$. Med.Sci. 23(1): 4-14.

Zhang, S., Qi, Y., Xu, Y., Han, X., Peng, J., Liu, K. \& Sun, C.K. 2013. Protective effect of flavonoid-rich extract from Rosa laevigata Michx on cerebral ischemia-reperfusion injury through suppression of apoptosis and inflammation. Neurochemistry International 63(5): 522-532.

Yeexing You \& Suzana Shahar*

Dietetics Programme

Centre for Healthy Ageing and Wellness (H-CARE)

Faculty of Health Sciences, Universiti Kebangsaan Malaysia Jalan Raja Muda Abdul Aziz

50300 Kuala Lumpur, Federal Territory

Malaysia

Yeexing You \& Suzana Shahar*

Head of Centre for Healthy Ageing and Wellness (H-CARE)

Faculty of Health Sciences

Universiti Kebangsaan Malaysia

Jalan Raja Muda Abdul Aziz

50300 Kuala Lumpur, Federal Territory

Malaysia

Hasnah Haron \& Hanis Mastura Yahya

Nutritional Sciences Programme

Centre for Healthy Ageing and Wellness (H-CARE) 
Faculty of Health Sciences Universiti Kebangsaan Malaysia Jalan Raja Muda Abdul Aziz 50300 Kuala Lumpur, Federal Territory Malaysia
*Corresponding author; email: suzana.shahar@ukm.edu.my

Received: 29 March 2018

Accepted: 5 July 2018 